\title{
Relationship between Corporate Social Responsibility and Corporate Governance
}

\author{
Dr. D.P.Verma ${ }^{1}$ Raj Kumar ${ }^{2}$ \\ ${ }^{I}$ Asstt. Professor Law (Selection Grade) H.P.University Regional Centre Dharamshala. H.P. \\ ${ }^{2}$ Asstt Professor Law, University of Jammu, J\&K.
}

\section{Introduction.}

Corporate Governance and Corporate Social Responsibility (CSR) are conceptualised by the Western countries, where their practices have developed tremendously in the last decade. During these periods the idea has been exported to other parts of the globe largely through the activities of multinational National companies. It may be noted that the Corporate Governance and CSR are two related and interwoven business concepts that are deeply embedded in business practices. In this context, an attempt is made to discuss the concept of CSR and Corporate Governance, and their interrelationship, within legal and regulatory framework in India.

\section{Definition Of CSR}

The idea of CSR largely started as a philanthropic gesture by a few wealthy businessmen. However, during the last decade the CSR is becoming buzz word in the corporate sector. The changing context within which companies operate, shaped by environmental and globalization forces, affects the way that the role of business is perceived. Now days, a growing number of companies worldwide have acknowledged the importance of CSR in doing business.

There is no universally accepted definition of the word "CSR", the meaning and definition of CSR depends upon on mainly two factors; Firstly, context in which it is used and secondly, stakeholder. The difficulties in defining precisely CSR are in part reflective of the way in which this topic has developed and the context of its use. For some, it has grown out of corporate philanthropy with a clear emphasis on social improvements or strategic investment keeping in view long term goals. For others, CSR has a much broader definition and is closely related to the sustainable development and environment issues.

CSR has been defined in many different ways. For the purpose of this paper, we will use three key definitions of the World Business Council for Sustainable Development, The European Union and the World Bank which covers all the elements of CSR.

\section{World Business Council For Sustainable Development (1999)}

CSR is the ethical behaviour of a company towards society; management acting responsibly in its relationship with other stakeholders who have a legitimate interest in the business, and it is the commitment by business to behave ethically and contribute to economic development while improving the quality of life of the workforce and their families as well as the local community and society at large.

\subsection{The European Union (2004)}

CSR is a concept whereby companies integrate social and environmental concerns in their business operations and in their interaction with their stakeholders on a voluntary basis.

In simple words, CSR may be defined as obligations and accountability of a company towards all of its stakeholders in its all operations.

\subsection{World Bank}

According to the World Bank, "Corporate social responsibility is the commitment of business to contribute to sustainable economic development by working with employees, their families, the local community and society at large to improve their lives in ways that are good for business and for development"

\section{Corporate Governance}

The concept of corporate governance was almost non-existent in India. In late 90's the concept of corporate governance was introduced in India by the Securities and Exchange Board of India (SEBI) through Listing Agreement, which is applicable to the listing companies only.

According to OECD the Corporate Governance structure specifies the distribution of rights and responsibilities among different participants in the corporation, such as, the Board, managers, shareholders and other stakeholders spells out the rules and procedures for making decisions on corporate affairs. 
According to Sir Adrian Cadbury, "Corporate Governance is the system by which companies are directed and controlled......"

Corporate governance may be defined as the broad range of policies and ethical practices which are adopted by an organisation in its dealing with the stakeholders.

\section{Relationship Between Corporate Governance And CSR}

The conceptualization of CSR was, initially, purely in terms of philanthropy or charity. However, the post-liberalization phase has seen a fundamental shift from this philanthropy-based model of CSR to a stakeholder- participation based model. Furthermore, CSR is gradually getting fused into companies' Corporate Governance practices. Both Corporate Governance and CSR focus on the ethical practices in the business and the responsiveness of an organisation to its stakeholders and the environment in which it operates. Corporate Governance and CSR results into better image of an organisation and directly affects the performance of an organisation.

The OECD principles on Corporate Governance, UN Global Compact Participation throw light on CSR scheme but in India CSR, by virtue of clause 49 of the listing agreement, have been made totally optional. It is pertinent to mention here that transparency, disclosure, sustainability and ethical behaviour is central theme in both CSR and Corporate Governance. Further, it is worthwhile to mention that CSR is based on the concept of self governance which is related to external legal and regulatory mechanism, whereas Corporate Governance is a widest control mechanism within which a company takes it management decisions. Furthermore, the objectives and benefits of CSR and Corporate Governance are similar in nature, some of them are stated herein below:

- Rebuilding of public trust and confidence by increased transparency in its financial as well as non-financial reporting and thereby increasing the shareholder value.

- Establishing strong brand reputation of the company.

- Making substantial improvement in its relationship with various stakeholders.

- Contributing to the development of the region and the society around its area of operation

- Addressing the concerns of its various stakeholders in a balanced way so as to maintaining a strong market position.

Furthermore, it may be worthwhile to note that in case of unlisted companies there is not robust system of corporate governance, although there are some provisions in the Companies Act, 1956, in this context the relationship between Corporate Governance and CSR is very important and significant. In order to appraise present position of CSR and Corporate Governance, it would be worthwhile to examine the legal and regulatory framework dealing with CSR and Corporate Governance.

\section{Legal Landscape Of Corporate Governance And CSR In India}

As corporate governance becomes increasingly driven by ethical norms and the need for accountability, and CSR adapts to prevailing business practices and legal framework, a potential convergence between them surfaces.

In India, the provisions relating to Corporate Governance and CSR are covered under following heads:

- The Companies Act, 1956 (applicable to both listed and unlisted companies)

-Securities and Exchange Board of India and regulations (applicable to listed companies)

It may be noted that for the unlisted companies the norms are made comparatively easier and are prescribed in the Companies Act, 1956. Whereas in case of listed companies, all the Companies Act, 1956 provisions are applicable and also the SEBI regulations, including the provisions of listing agreement with Stock Exchange, for transparency, disclosure and corporate governance are applicable.

\subsection{The Companies Act, 1956}

The Companies Act, 1956 is applicable to all type of companies, both listed and unlisted companies. The Act contains elaborate provisions about the functioning of companies and appointment, role, position, responsibilities and liabilities of board of directors as well as protection of interest of investors in cases of oppression and mismanagement.

One of the important provisions is contained in section 252 of the Act, which provides for appointment of small shareholders' director by a company. At the same time, Section 292 of the Companies Act, 1956 restricts powers of the Directors on various matters. Also, Section 372 A restricts powers of companies to give loan, guarantee etc with obtaining prior approval of shareholders.

\subsection{Clause 49 of the Listing Agreement}

SEBI's Kumar Mangalam Birla Committee on Corporate Governance brought in substantial change in Corporate Governance norms through change in the listing agreements of Stock Exchanges, more particularly Clause 49 in the Listing Agreement. 
Clause 49 of the Listing Agreement with Stock Exchange, which is applicable to all listed companies, contains elaborate provisions to improve the quality of corporate governance ensuring transparency, disclosure, appointment of independent directors, remuneration committee and audit committee.

\section{3 . The Companies Bill, 2011}

As per the latest draft of the Companies Bill, 2011 as finalised by the Ministry of Corporate Affairs, it has been decided to take a middle-path in enforcing CSR by giving companies the choice to either spend two percent of their net profits on philanthropic activities, or mandatorily explain why they could not do so. In the earlier draft there was mandatory obligation on the companies to spend two percent of their profits on CSR activities, This has diluted the proposed mandatory CSR spending provision due of the corporate sector's serious objections to it.

Further, the Companies Bill 2011 has taken significant step by incorporating, under Clause 216, provisions relating to Class Action or Derivative Action. Class Action and Derivative Action are exceptions to the rule of Foss v. Harbottle which talks about majority rule. Corporate democracy is on the notion of participative management and shareholders take decisions by resolutions and decisions of the majority will prevail. In the case majority commits fraud and misfeasance thereby corporate right of minority is infringed then they can file a suit in the name of company under Class and Derivative Action

In India till now in a very limited way Class and Derivative action in Corporate Governance was allowed under Section 397 and 398 of Companies Act, 1956 in case of oppression and mismanagement. Whereas, under Clause 216 of the Companies Bill provides for Class Action and Derivative Action in order to protect interests of minority shareholders, this will further strengthen the mechanism of Corporate Governance.

\section{Conclusion}

For many years, the approach of companies on the role of business in society could be summarized with the following words of Milton Friedman: "there is one and only one social responsibility of business to increase its profits" and "Business of business is business". However, it may be worthwhile to mention that the world has moved far ahead from the aforesaid words of Milton Friedman, now a day's Corporate Governance and CSR are integral part of any company.

It may be noted that, at present, the provisions of Corporate Governance are mandatory and recommendatory under various provisions discussed hereinabove. However, there is no concrete system for CSR, it is purely optional. Furthermore, since Corporate Governance and CSR is interrelated and complementary to each other, by incorporating CSR provisions within Corporate Governance framework would be beneficial for India.

\section{[1]. Stakeholder is a broader concept than shareholder and it includes:}

- Country and Government;

- Customers ;

- Shareholders and providers of capital ;

- Suppliers and vendors,

- Employees.

[1]. Organization for Economic Co-operation and Development

[2]. Sudip Mahapatra and Kumar Visalaksh, Emerging Trends In Corporate Social Responsibility: Perspectives And Experiences From Post-Liberalized India, available at http://www.csrweltweit.de/uploads/tx_jpdownloads/Sudip-Emerging_Trends_in_Corporate_Social_Responsibility1.pdf last accessed on 25th December 2011.

[3]. Uday M. Karnik, CSR - A Challenge for the Corporates, Chartered Secretaries, 39(6) 2009.737-742.

[4]. Naresh Kumar, Shareholders Activism - Healthy Trend for Corporate Governance, Chartered Secretary, 39(8) 2010. 1075-1080.

[5]. $\quad$ www.nujscfsl.com last accessed on $25^{\text {th }}$ December 2011. 